\title{
Electrochemical Properties and XPS Analysis of Ni-B/SiC Nanocomposite Coatings
}

\author{
Weiwei Zhang ${ }^{1, *}$, Baosong $\mathrm{Li}^{2, *}$ \\ ${ }^{1}$ College of Mechanical and Electrical Engineering, Hohai University, Changzhou 213022, China \\ 2 \\ College of Mechanics and Materials, Hohai University, Nanjing 211100, China \\ *E-mail: zdzdq@126.com, lbs79@126.com
}

doi: $10.20964 / 2018.04 .30$

Received: 17 December 2017 / Accepted: 30 January 2018 / Published: 6 March 2018

\begin{abstract}
Few studies have reported the electrochemical properties and XPS analysis of Ni-B/SiC nanocomposite coatings with high wear resistance prepared by electro-co-deposition. In this study, Ni$\mathrm{B} / \mathrm{SiC}$ nanocomposite coating was prepared by electrodeposition using trimethylamine borane as boron source in a Ni-B electrolyte containing dispersed $\mathrm{SiC}$ nanoparticles. The corrosion resistance and antiwear properties of the $\mathrm{Ni}-\mathrm{B} / \mathrm{SiC}$ composite coating were examined. XPS was employed to analyze the element electronic state of the coating surface. The results show that the corrosion resistance of the Ni$\mathrm{B} / \mathrm{SiC}$ composite coating was enhanced which may be related to the dense structure, barrier effect and the reduction in the active surface area of Ni-B matrix by the presence of inert SiC particles. The XPS analysis indicated that the as-deposited coating contains metallic nickel, oxide or hydroxide nickel, and the $\mathrm{SiC}$ particles. Ni-B/SiC nanocomposite coating with dense structure shows superior anti-corrosion and wear resistance than $\mathrm{Ni}-\mathrm{B}$ and $\mathrm{Ni} / \mathrm{SiC}$ coatings.
\end{abstract}

Keywords: Electrodeposition; Ni-B/SiC nanocomposite coating; wear resistance; corrosion resistance; microhardness

\section{$\underline{\text { FULL TEXT }}$}

(C) 2018 The Authors. Published by ESG (www.electrochemsci.org). This article is an open access article distributed under the terms and conditions of the Creative Commons Attribution license (http://creativecommons.org/licenses/by/4.0/). 